with the disease were introduced. With colonies of 27 and 30 tame, and 55 and 44 wild, rabbits, the fatality was $99 \cdot 6$ per cent among the tame, and 100 per cent among the wild. The disease originally came from epizootics among tame rabbits in South America.

\section{Research at Millport}

The Annual Report of the Executive to the Council of the Scottish Marine Biological Association for 1934-35 includes the director's report on research. Drs. Orr, Marshall and Nicholls are concentrating on the development and food of the herring from hatching onward. In this connexion, it is found that copepods are by far the most important food organisms, the larval and post-larval herring eating chiefly the small species. In view of this fact, it was decided to investigate seasonal distribution and breeding periods of these small copepods, in the same way as has already been done for Calanus finmarchicus. Results so far show that in the early months Microcalanus pusillus and Oithona helgolandica were the most abundant species, with Pseudocalanus elongatus, Centropages hamatus, Temora longicornis and Acartia clausi occurring in smaller numbers. Most of the important planktonic organisms have been weighed, and in some cases the chemical composition determined. During the winter, when zooplanktonic organisms are scarce, a beginning was made on the analysis of non-planktonic animals important as fish food. Investigations on shore ecology, especially in Kames Bay, by Dr. A. C. Stephen and Mr. Elmhirst, have been continued. The work already done has shown a very rich fauna important for fish food. Various fishes from the seine net have been examined and shown to feed on the dominant invertebrates. A very interesting feature in these investigations is the work by Dr. Nicholls on sand-dwelling copepods, especially minute species living in the interstices between the sand grains on the beach. Several new species of these and three new genera have been found. Other researches include algal ecology and preserving colour in green seaweeds, experiments on timber preservation in the sea and the growth of the dog-fish Acanthias.

\section{Seismology in New Zealand}

THE report of Dr. C. E. Adams, Dominion Astronomer and Seismologist, for the year 1934 (Dept. Sci. Indus. Res. Bull., No. 105) shows that the seismic activity of New Zealand was much greater during that year than in 1933, the number of earthquakes felt being 230 , instead of 108 . Of these, 158 were felt in the North Island only, 60 in the South Island only, and 12 in both islands. The most important shock was that of March 5 at 11.16 p.m. N.Z. time (11.46 a.m., G.M.T.). Its intensity in several parts of northern Wairarapa reached the degree 9 of the Rossi-Forel scale and chimneys fell over a wide area in the southern part of the North Island. The map that accompanies the paper shows that most of the epicentres lay in the extreme north of South Island and the southern half of North Island. Owing to the increased activity off the east coast of the latter island and to other changes that have been reported along the coast, it is strongly recommended that a detailed marine survey should be carried out of the whole east coast, including soundings in the seas to the east of New Zealend.

\section{Solar Activity and Terrestrial Phenomena}

Is 1924 the International Research Council (now transformed into the International Council of Scientific Unions) formed a Commission for the Study of Solar and Terrestrial Relationships, a field of science which extends over the domains of at least three of the International Scientific Unions. This Commission, among other activities, has published triennial reports, reviewing the state and progress of knowledge on solar and terrestrial relationships, and, where necessary, making recommendations regarding action that may conduce to further progress. These reports are distributed to certain libraries and to institutions and individuals occupied in work relating to the subject. The fourth report has recently been issued (Conseil International des Unions Scientifiques : Quatrième Rapport de la Commission pour l'Etude des Relations entre les Phénomènes Solaires et Terrestres; pp. 159. Firenze, 1936) under the editorship of the president of the Commission, Prof. G. Abetti, Astrophysical Observatory, Arcetri, Italy. It differs from its predecessors in being better and more attractively produced, and in having a valuable 28-page introduction by the editor, giving a general survey of the subject for the past three years. The remainder of the volume consists of twenty-one brief articles on different aspects of the subject, by various authors.

\section{Electric Supply in the Irish Free State}

THE annual report of the Electricity Supply Board of the Irish Free State for the year ending March 31, 1936 shows that a further increase in the sale of electricity has been effected, and results in a surplus of income over expenditure of about $£ 310,000$. The total capital expenditure is now about $10 \frac{1}{2}$ million pounds, of which 5 per cent is paid to the State. The total sale of electric units during the year amounted to 187 millions, and the average receipts per unit dropped from $1 \cdot 92 d$. to $1 \cdot 84 d$. The figures show a very satisfactory acceleration in the development of the consumption of electricity for domestic purposes. In the environs of Dublin the consumption increased by 63 per cent. The total units generated during the year were 243 millions, of which 211 millions were supplied by the hydro-electric power station on the Shannon. Details are given of the extension of plant, and the building of new works on the Shannon and at the Pigeon House in Dublin. Two Swiss experts have reported on the development of the River Liffey for hydro-electric purposes. As it is the intention of the Corporation of the City of Dublin to use the water-storage reservoir on the Liffey to augment the ordinary water supply to the city, it was found inadvisable to take full advantage of the Liffey water-power project for six or seven years. As soon as the necessary legislative provision has been obtained, the work on the reservoir will be 
begun. The average yearly production of the Liffey hydro-electric development is computed to be 30 million units.

\section{Scientific and Technical Literature}

SEveral suggestions for the improvement of scientific and technical literature are made by Commander T. W. Macalpine in the Publishers' Circular and the Publisher and Bookseller of July 18. Criticizing the present procedure followed by a specialist or a publishing company in regard to a projected scientific book, he suggests that the exposition of the subjects treated in scientific and technical works, etc., would be improved, their utility for easy and quick reference increased, the cost of production decreased, and their filing and storage on shelves, etc., facilitated, if there existed an independent body of recognized standing in the world of science which could furnish authors and publishers with general information and guidance. At present an author is rarely able to give much information of assistance to the publishers on such matters as form of treatment, size of volume, number of words, type or types, number and kind of illustrations, diagrams, paper, binding. Accordingly, the utility of a book is liable to be limited by the publisher's experience. An independent advisory body of recognized standing which could supply information on such matters, assist in the standardization of nomenclature and symbolism, as well as of formats and sizes of printed area on pages, and advice on subdivision, synopsis, contents list and index, etc., would make an important contribution to efficient publication.

\section{Composition of Cereal Straw}

THE seemingly facetious title, "The Two Ends of Straw", appears over an article by Dr. H. Nicol in Agricultural History (10, No. 1, Jan. 1936), reviewing some early, but fundamental, research upon the composition of cereal straw. The work of Prof. J. F. W. Johnston in 1842, of J. P. Norton and P. F. H. Fromberg in 1845 , and of J. I. Pierre in 1863 and 1866 is collected to show that straw has a great diversity of composition between the root end, and the parts towards the flower. The work of Pierre is particularly detailed, and supplies a great deal of material not widely known at the present day. Dr. Nicol discusses some of the results in relation to the recent hypothesis of 'negative migration' of plant constituents, where nitrogen and mineral elements are returned to the soil. Several additional papers upon the partitional analysis of straw have come to light since the publication of the article under review, but the most recent is dated 1879. There is considerable gratification, but also cause for humble reflection, that modern ideas are being confirmed by work which has remained in oblivion for nearly sixty years.

\section{Greenkeeping Research}

THE spring number of the Journal of the Board of Greenkeeping Research (4, No. 14, from the Board's
Research Station, St. Ives, Bingley, Yorks, 2s. $6 d$. net) contains the annual report of the organization, which shows, inter alia, a very gratifying volume of advisory work. Many suggestions for future work of a practical kind have been made by the Greenkeepers' Advisory Committee, and the report of last year's annual conference is embellished by the full text of Prof. N. M. Comber's address on "The Constitution of Soil". Mr. R. B. Dawson, director of the Research Station, contributes a short but highly informative article on camomile lawns, and the previous accounts of lawn grasses, of weeds, and of fertilizers, are continued. The difficulties of accurate botanical description are being met by the publication of a glossary of botanical terms. Mr. R. B. Ferro discusses some of the difficulties of field experimentation on the golf course. Two short articles on water installations, a description of the management of a golf course on heavy clay soil, and a plea for special investigation of bowling green problems, are included in the issue.

\section{A Journal of Marriage Hygiene and Birth Control}

WiтH the May issue (2, No. 4), Marriage Hygiene completes its second year. The objects of this quar. terly journal are to secure for conjugal hygiene a proper place in preventive medicine, to publish scientific contributions treating marriage as a social and biological institution, and to promote and coordinate contraceptive clinics and marriage consultation centres in various parts of the globe. Each number contains notes and comments, original articles, reviews and abstracts of current literature. "The Positive Side of Birth Control" (E. B. Reuter), "Birth Prevention in France" (J. J. Spengler), and "Artificial Insemination" (H. Brewer) are some of the original articles in the present number. The yearly subscription for the volume of about five hundred pages is 18s. It is published from Kodak House, Bombay 1, India, the editor being A. P. Pillay. The London agents are Messrs. H. K. Lewis and Co., 136 Gower Street, W.C.l.

\section{Anti-Noise Regulations}

THE City Council of Philadelphia has adopted a noise abatement ordinance prepared by a Special Committee of the Philadelphia County Medical Society. The ordinance prohibits sounding of motorhorns except when absolutely necessary for the prevention of accidents, building operations at night except by special permit, the use of sound devices by pedlars, unnecessary noise in handling rubbish cans, and the use of gongs, sirens or exhaust whistles on any vehicles except those of the police and fire bureaux, and hospitals. Loud playing of radios in homes or in front of stores is also among the specific noises forbidden in the ordinance.

\section{Costing Returns of Hospitals and Sanatoria}

IN recent years, the value of costing methods in securing business efficiency has become increasingly recognized, not only in industry but also in local government. The Ministry of Health has issued Part 1 